\title{
Real-time detection of antibiotics cytotoxicity in rabbit periosteal cells using microfluidic devices with comparison to conventional culture assays
}

\author{
Chih-Hao Chiu ${ }^{1,2 \dagger}$, Kin Fong Lei ${ }^{2 \dagger}$, Yi-Sheng Chan ${ }^{1}$, Steve W. N. Ueng ${ }^{1}$ and Alvin Chao-Yu Chen ${ }^{1 *}$ (D)
}

\begin{abstract}
Background: Local antibiotic application has been widely used in orthopedic surgery. The dose-related toxicity of antibiotics towards periosteal tissues and resulting effects on osteogenic expression are yet to be studied.

Methods: Periosteal cells harvested from the medial tibia of New Zealand White rabbits were used. A seeding density of $5 \times 10^{3}$ cells $/ \mathrm{cm}^{2}$ was determined to be optimal for testing in the pilot study; the cells were cultured in xCELLigence 96-well plates. Microfluidic impedance analyzers were used to monitor cellular proliferation in microfluidic culture systems with exposure to three different concentrations $(10 \mu \mathrm{g} / \mathrm{mL}, 100 \mu \mathrm{g} / \mathrm{mL}$, and $1000 \mu \mathrm{g} / \mathrm{mL})$ of cefazolin, ciprofloxacin, and vancomycin, respectively. The correlation of cell index at day 7 with optical density values from WST-1 assays using conventional cultures was evaluated by calculating the Pearson's coefficient. RNA analysis was performed to investigate the expression of osteogenic markers in the cultured cells, including core-binding factor alpha 1 (Cbfa1), osteopontin (OPN), and osteopontin promoter (OPNp), relative to glyceraldehyde-3-phosphate dehydrogenase (GAPDH) as the endogenous control.

Results: A significant dose-related inhibition of cell index was found for all the 3 antibiotics, whereas the WST-1 assays showed a significant dose-related inhibition of cellular proliferation only at a high dose of cefazolin $(1000 \mu \mathrm{g} / \mathrm{mL})$ and medium-to-high dose of ciprofloxacin $(100 \mu \mathrm{g} / \mathrm{mL}$ and $1000 \mu \mathrm{g} / \mathrm{mL})$. Pearson's coefficient analysis indicated a high correlation between the cell index and optical density values of WST-1 assays only for medium and high doses of ciprofloxacin $(100 \mu \mathrm{g} / \mathrm{mL}$ and $1000 \mu \mathrm{g} / \mathrm{mL})$; a moderate correlation was seen for cefazolin, and a low dose of ciprofloxacin $(10 \mu \mathrm{g} / \mathrm{mL})$. RNA analysis confirmed significant dose-related inhibition of cfba1, OPN, and OPNp expression by all three antibiotics.
\end{abstract}

Conclusion: With optimal seeding amounts, rabbit periosteal cells can be dynamically monitored in the xCELLigence microfluidic system. Dose-related inhibition of cellular proliferation and osteogenic expression was found after exposure to cefazolin and ciprofloxacin. By providing real-time detection and exhibiting comparable correlation, microfluidic impedance-based analyzer is a feasible alternative to the conventional WST-1 assays.

Keywords: Impedance, Periosteum, Antibiotics, Cytotoxicity, Microfluidic, Cell index, WST-1, Osteogenic

\footnotetext{
* Correspondence: alvinchen@cgmh.org.tw

${ }^{\dagger}$ Chih-Hao Chiu and Kin Fong Lei contributed equally to this work.

${ }^{1}$ Bone and Joint Research Center, Department of Orthopedic Surgery, Chang

Gung Memorial Hospital-Linkou and University College of Medicine, 5th,

Fu-Shin Street, Kweishan Dist, Taoyuan 333, Taiwan, Republic of China

Full list of author information is available at the end of the article
}

(c) The Author(s). 2019 Open Access This article is distributed under the terms of the Creative Commons Attribution 4.0 International License (http://creativecommons.org/licenses/by/4.0/), which permits unrestricted use, distribution, and reproduction in any medium, provided you give appropriate credit to the original author(s) and the source, provide a link to the Creative Commons license, and indicate if changes were made. The Creative Commons Public Domain Dedication waiver (http://creativecommons.org/publicdomain/zero/1.0/) applies to the data made available in this article, unless otherwise stated. 


\section{Background}

Local injections often are used in the management of common musculoskeletal conditions [1-3]. Among these agents, antibiotics have been empirically used for the prevention and treatment of bone and joint infection for several decades [4]. Antibiotic-loaded carriers were designed not only to eradicate bone infection but also to facilitate trabecular bone formation [5]. However, currently, there are no available data regarding the doserelated cytotoxicity of antibiotics towards periosteal tissues, and their resulting effects in osteogenesis have not yet been meticulously surveyed.

A commercial microfluidic cell analyzer called the xCELLigence system (xCELLigence, Roche/ACEA Biosciences, CA) performs an impedance-based analysis, allowing the label-free dynamic monitoring of relatively viable and adherent cell amounts [6] and has been applied for the real-time detection of cell migration and proliferation in cancer immunotherapy [7], cytotoxicity [8], and drug resistance research [9]. Recently, this technology has been exploited to investigate the cellular profiles of osteoprogenitors derived from human jaw periosteum; it has shown potential to be used for engineering applications in maxillofacial orthopedic surgery [10].

In this study, we proposed a non-invasive, label-free research model in cultured cells. Rabbit periosteal cell proliferation and responses to different drugs were recorded using both the xCELLigence system and conventional cell proliferation assays. End-point results of cell proliferation were compared by using the two methods. We hypothesize that the xCELLigence biosensor technology can serve as a valuable platform for the real-time monitoring of rabbit periosteal cell behavior and responses to different stimuli.

\section{Methods}

We used animals from the Laboratory Animal Center, Chang Gung Memorial Hospital-Linkou. Written informed consent (2015122504) was obtained from the Institutional Animal Care and Use Committee (IACUC) to use the animals for executing this study. The animal use protocol listed below has been reviewed and approved by the IACUC, and the Committee recognized that the proposed animal experiment follows the Animal Protection Law by the Council of Agriculture, Executive Yuan, R.O.C. and the guideline as shown in the Guide for the Care and Use of Laboratory Animals s promulgated by the Institute of Laboratory Animal Resources, National Research Council, U.S.A. After completion of the study, all the experimental animals were taken care by the Laboratory Animal Center and ultimately euthanized with intramuscular Zoletil $50(0.5 \mathrm{~mL} / \mathrm{kg})$ and intravenous $2 \%$ Lidocaine $(5 \mathrm{~mL})$ on reaching humane endpoints.

\section{Periosteum harvest and isolation of cells}

Under anesthesia by using intramuscular injection of Zoletil $50(0.5 \mathrm{~mL} / \mathrm{kg})$ and sterile conditions, a 3-cm skin incision was made along the medial tibias of 6 adult male New Zealand White rabbits in a single animal group. The harvested periosteum was sectioned into pieces washed twice in calcium- and magnesium-free Dulbecco's phosphate-buffered saline (DPBS) and then finely minced. The cells were released by treatment with $0.3 \%$ collagenase II for $2 \mathrm{~h}$ in low-glucose Dulbecco's modified Eagle's medium (LG DMEM) containing antibiotic solution (100 $\mathrm{U} / \mathrm{mL}$ penicillin and $100 \mathrm{mg} / \mathrm{mL}$ streptomycin) with gentle agitation. After the same volume of DPBS was added, the undigested tissue was removed using a $100-\mathrm{mm}$ nylon sieve. After centrifugation, cells were collected and then washed twice. Finally, for further use, they were resuspended in LG DMEM supplemented with 10\% fetal bovine serum (FBS) and antibiotic solution. The genotype of the periosteal cells was confirmed by real-time polymerase chain reaction (PCR) for detecting the osteogenic markers. Normal morphologic characteristics were confirmed by microscopy with elongated change of periosteal cells noted in differentiating passage after passage (Fig. 1). Since high mRNA expression of CBFA1, OPN, OPNp was found in low-passage, only cells in the 2nd passage were used in the experiments.

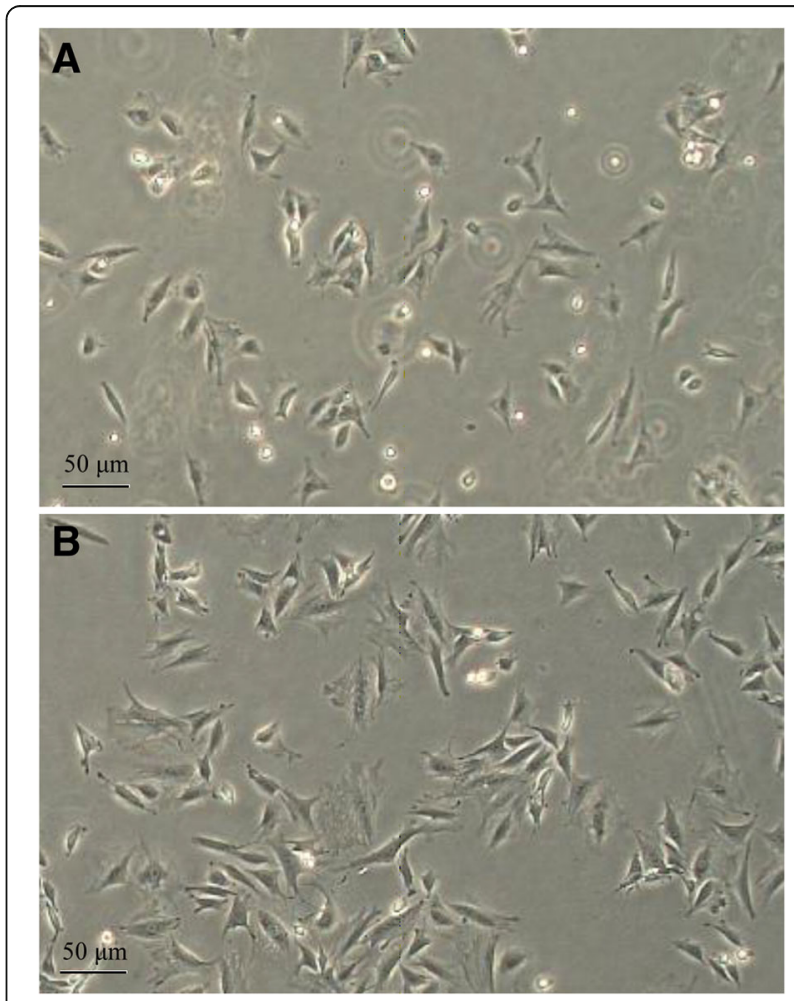

Fig. 1 Microscopic morphology of periosteal cell culture. a Second passage. $\mathbf{b}$ Third passage 


\section{Antibiotics preparation and exposure}

Antibiotics in different concentrations were added to the cells in triplicate $24 \mathrm{~h}$ after seeding. Each drug was prepared in three different concentrations: $10 \mu \mathrm{g} / \mathrm{mL}$, and $100 \mu \mathrm{g} / \mathrm{mL}$ and $1000 \mu \mathrm{g} / \mathrm{mL}$ (equal to 10 times and 100 times the clinical dosage, respectively); $10 \mu \mathrm{L}$ of each of the antibiotic solutions was then added to the wells. Control groups were exposed to a saline solution with the same conditions without antibiotics (saline control). We used the same xCELLigence system and WST-1 assay as that in our previous tenocyte research [11] for cellular proliferation assessment. Cytotoxicity of the drugs on periosteal cells in comparison to that of the non-drug saline control was expressed as cell index adhesion curves for the xCELLigence system, and as optical densities in the WST-1 assay for the conventional culture plate method.

\section{Cell seeding into xCELLigence $96-$ well plates}

Complete media $(50 \mu \mathrm{L})$ was firstly put into each well of the xCELLigence 96-well plates. After equilibration to $37^{\circ} \mathrm{C}$, the plates were applied into the $\mathrm{xCELLigence}$ station; baseline impedance was then measured. All wells and connections were ensured to work properly within the acceptable limits. Under three different concentrations $\left(5 \times 10^{3}\right.$ cells $/ \mathrm{cm}^{2}, 1 \times 10^{4}$ cells $/ \mathrm{cm}^{2}$, and $2 \times 10^{4}$ cells $\left./ \mathrm{cm}^{2}\right)$, the cells were then seeded into the wells for a pilot test to select an optimal cell seeding density for antibiotics exposure.

\section{Software and data plotting of xCELLigence system}

Software version 1.2.1 of xCELLigence system was used in this experiment to have electronic documentation regarding the experimental details. The cell index indicates the amount of cellular adhesion in each well with cell index approaching zero indicating absence of living cells or in a suspension of dead cells. With cellular attachment onto the electrode, the measured signal was confirmed to correlate linearly with the cell amount throughout the experiment.

\section{Cell proliferation in conventional WST-1 assay}

Periosteal cells were cultured inside conventional 24well plates and awaited to adhere overnight. The cells were exposed to the same antibiotics concentrations used for the tests inside the xCELLigence system on the next day. The culture medium was then refreshed every third day until the day 7 after drug exposure when cell growth was analyzed using a WST-1 kit (Roche, Basel, Switzerland). By using the colorimetric WST-1 assay that was based on the cleavage of tetrazolium WST-1 into orange formazan by mitochondrial dehydrogenases in viable cells, the level of orange formazan increases when mitochondrial activity increases and can be quantified through an E LISA Reader (MWG-Biotech, Ebersberg, Germany) at $450 \mathrm{~nm}$ with a reference wavelength of $245 \mathrm{~nm}$.

\section{Quantitative real-time PCR assay}

With completion of the ultimate impedance measurement, ribonucleic acid (RNA) was isolated from the cell culture in the xCELLigence 96-well plates using the TRIzol reagent (Invitrogen, Carlsbad CA) as we described in previous publication [11]. The uQuant software was used to measure the RNA quantity and purity (A260/ 280). RNA was reverse-transcribed into cDNA using $1 \mu \mathrm{g}$ of mRNA and a High Capacity Reverse Transcription kit (Invitrogen, Carlsbad, CA). With 10-100 ng of cDNA as a template, real-time PCR was performed using the StepOne Real-Time PCR System (Applied Biosystems, Foster City CA). The resulting cycle threshold $(\mathrm{Ct})$ values were normalized and analyzed using the standard curve method. By using the TaqMan Gene Expression Assays, expression levels of core-binding factor alpha 1 (Cbfa1), osteopontin (OPN), and osteopontin promoter (OPNp) were obtained, relative to the levels of glyceraldehyde-3-phosphate dehydrogenase (GAPDH), which was the endogenous control (Table 1).

\section{Statistical analysis}

Each experiment was repeated in triplicate. Cell proliferation in response to different antibiotic concentrations was compared by the independent $t$ test regarding the cell index results in the xCELLigence system and optical density results from the WST-1 assays in conventional cultures. Correlations between cell index results from the xCELLigence system and cell proliferation results (based on the optical densities) from the WST-1 assays were assessed by the Pearson correlation analysis. Pearson's correlation coefficients ( $\mathrm{r}$ ) of 0.4 to 0.69 indicate moderate correlation, whereas values between 0.7 and 0.99 indicate a high correlation. All statistical analyses

Table 1 Primers for reverse-transcription PCR (RT-PCR) to determine osteogenic gene expression

\begin{tabular}{ll}
\hline Gene & Primer sequence \\
\hline GAPDH & Sense: 5'-GCCTGGTCACCAGGGCTGC-3' \\
& Antisense: 5'-TGCTAAGCAGTTGGTGGTGCA-3'. \\
Cbfa1 & Sense: 5'-CCGCACGACAACCGCACCAT-3' \\
& Antisense: 5'-CGCTCCGGCCCACAAATCTC-3' \\
OPN & Sense: 5'-CCAAGTAAGTCCAACGAAAG-3' \\
& Antisense: 5'-ATGTCTGCTCCTGTAGTGG-3' \\
OPNp & Sense: 5'-CAGAATGCTATGTCCTCAGA-3' \\
& Antisense: 5'-CGTCCTCATCCTCATCAATA-3'
\end{tabular}

GAPDH glyceraldehyde-3-phosphate dehydrogenase

Cbfa1 core-binding factor subunit alpha-1

OPN osteopontin

OPNp ONP promoter 
were performed with SPSS 21.0 for Windows (SPSS Inc.; Delaware, Ohio).

\section{Results}

\section{Selection of optimal cell seeding density}

We used three different cell concentrations $\left(5 \times 10^{3}\right.$ cells/ $\mathrm{cm}^{2}, 1 \times 10^{4}$ cells $/ \mathrm{cm}^{2}$, and $2 \times 10^{4}$ cells $/ \mathrm{cm}^{2}$ ) to determine the optimal number of cells for seeding in the pilot study (Fig. 2). In case of the rabbit periosteal cells, adhesion was slow initially. Then the cell index increased steadily over the first few hours after seeding, followed by a period of rapid proliferation. The proliferative phase was found at all seeding densities, and as expected, occurred more slowly at lower seeding densities. When $5 \times 10^{3}$ cells $/ \mathrm{cm}^{2}$ were seeded, the cell index was $0.4 \pm 0.01$ after $24 \mathrm{~h}$ of cell adherence and continuously increased to $1.4 \pm 0.2$ at the final time point $(166 \mathrm{~h})$. Cell indices for the seeding densities of $1 \times 10^{4}$ cells $/ \mathrm{cm}^{2}$ and $2 \times 10^{4}$ cells $/ \mathrm{cm}^{2}$ steadily increased and then slightly decreased, and changed from $0.6 \pm 0.01$ to $2 \pm 0.2$ and $1.2 \pm 0.02$ to $2.5 \pm 0.12$, respectively, at the final time point. After the pilot study, $5 \times 10^{3}$ cells $/ \mathrm{cm}^{2}$ was chosen as the optimal seeding density for the drug tests.

Real-time cell index of periosteal cells exposed to antibiotics, and comparison with conventional cell proliferation assay In the pilot study, a proper seeding density of $5 \times$ $10^{3}$ cells $/ \mathrm{cm}^{2}$ was selected for the xCELLigence system. After $24 \mathrm{~h}$ of cell adherence, 3 different concentrations of antibiotics were added to determine their real-time influence on cells. Cell proliferation was determined by the cell index in the xCELLigence system and WST-1 proliferation assays using conventional cultures (Fig. 3).

\section{Real-time cell index of periosteal cells exposed to antibiotics}

Cell index was measured at day 7 with a seeding density of $5 \times 10^{3}$ cells $/ \mathrm{cm}^{2}$ periosteal cells (Fig. 4). The average cell index was $4.66 \pm 1.33$ in the control group, and changed to $4.97 \pm 1.45,2.57 \pm 0.7$, and $0.12 \pm 0.03$ upon exposure to $10 \mu \mathrm{g} / \mathrm{mL}, 100 \mu \mathrm{g} / \mathrm{mL}$, and $1000 \mu \mathrm{g} / \mathrm{mL}$ of cefazolin, respectively. The average cell indices were $4.31 \pm 2.15,2.54 \pm 0.95$, and $0.06 \pm 0.03$, upon exposure to $10 \mu \mathrm{g} / \mathrm{mL}, 100 \mu \mathrm{g} / \mathrm{mL}$, and $1000 \mu \mathrm{g} / \mathrm{mL}$ of ciprofloxacin, respectively. The average cell indices were $3.94 \pm$ $1.40,2.73 \pm 0.56$, and $2.05 \pm 0.62$, upon exposure to $10 \mu \mathrm{g} / \mathrm{mL}, 100 \mu \mathrm{g} / \mathrm{mL}$, and $1000 \mu \mathrm{g} / \mathrm{mL}$ of vancomycin, respectively. A significant difference was noted in case of all the antibiotics, when their dosages were increased to the medium and high concentrations $(100 \mu \mathrm{g} / \mathrm{mL}$ and $1000 \mu \mathrm{g} / \mathrm{mL}$ ) (Fig. 4).

\section{Conventional cell proliferation assay of periosteal cells exposed to antibiotics}

When the periosteal cells were exposed to different concentrations of antibiotics in the conventional culture system, at day 7, the WST-1 assays revealed a dose-related effect on cellular proliferation. The optical density averaged $1.41 \pm 0.35$ upon exposure to $10 \mu \mathrm{g} / \mathrm{mL}$ cefazolin,

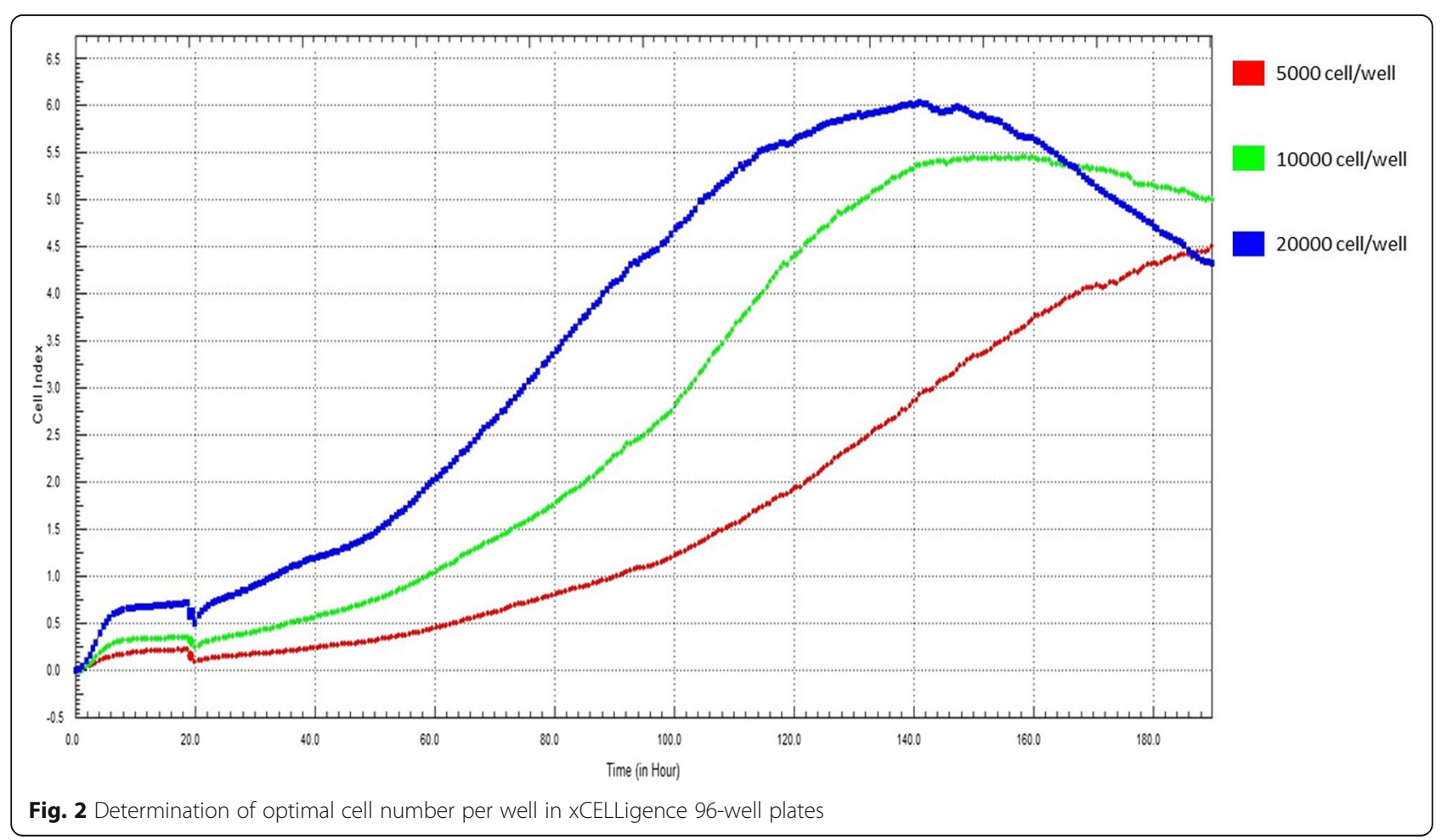



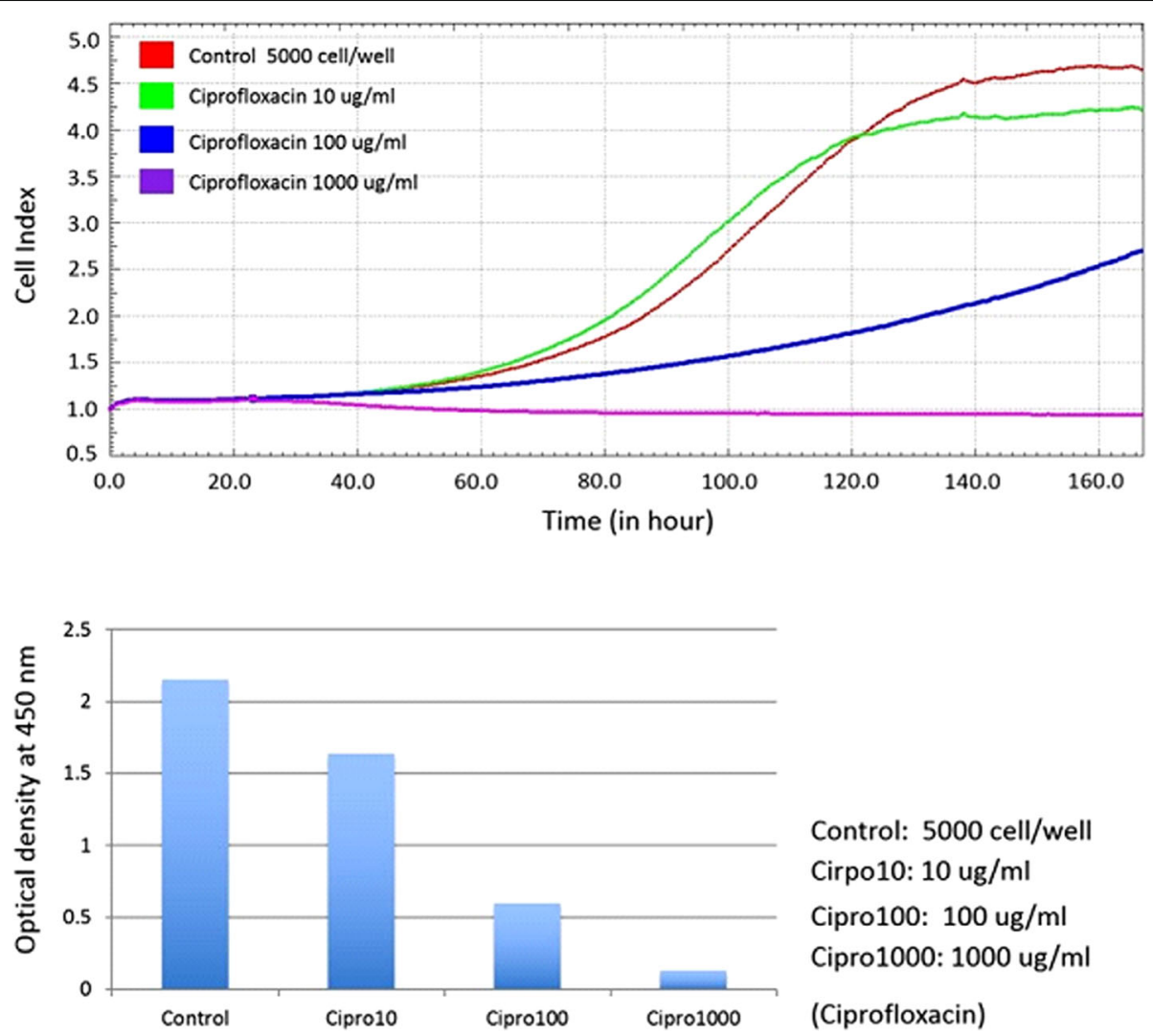

Fig. 3 Ciprofloxacin cytotoxicity on periosteal cell proliferation. Ciprofloxacin cytotoxicity was expressed as cell index adhesion curves from the xCELLigence system (above) and as optical densities at $450 \mathrm{~nm}$ in the WST-1 assay from the conventional culture plate 7 days (below)

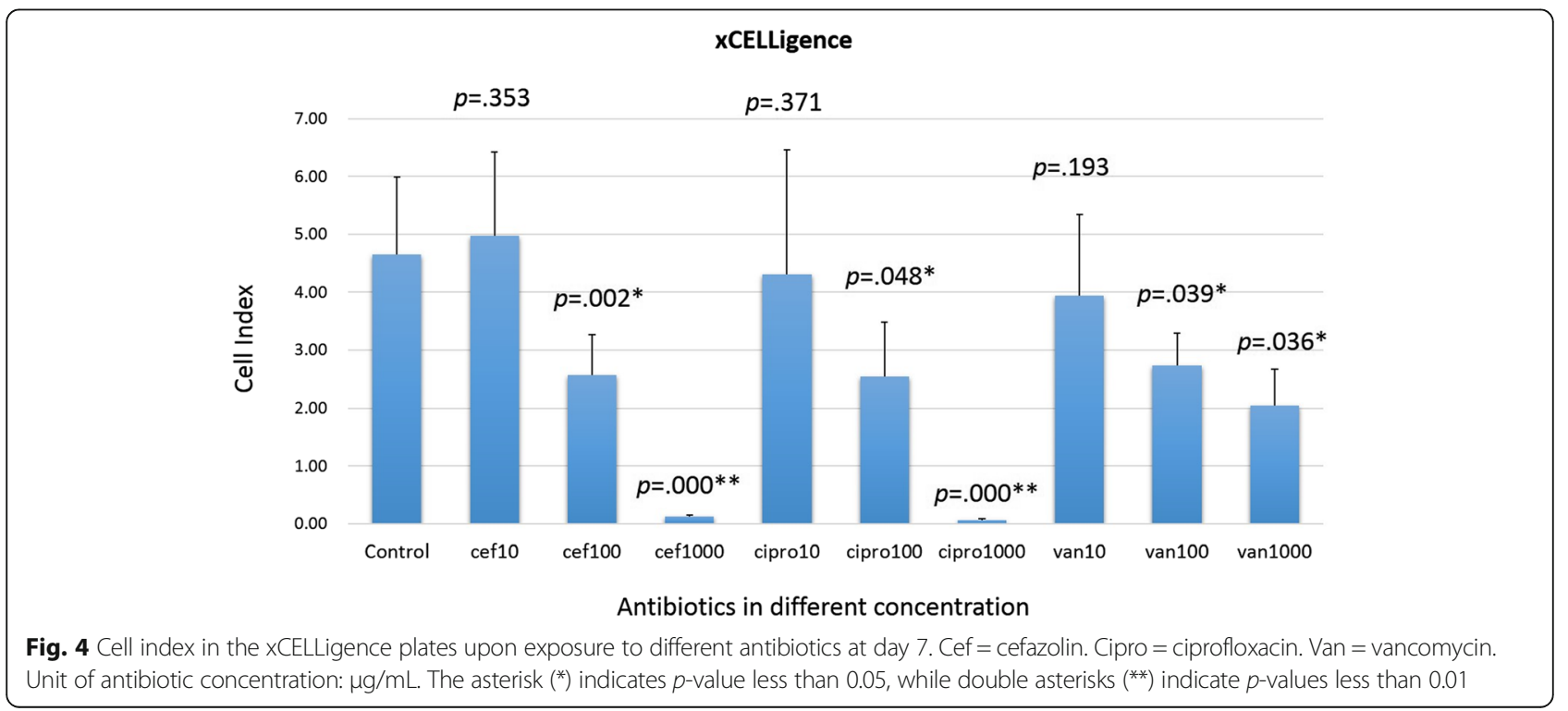


and then increased to $1.39 \pm 0.57$ and decreased to $0.14 \pm$ 0.05 , upon exposure to $100 \mu \mathrm{g} / \mathrm{mL}$ and $1000 \mu \mathrm{g} / \mathrm{mL}$ cefazolin, respectively. The optical density upon exposure to $10 \mu \mathrm{g} / \mathrm{mL}, 100 \mu \mathrm{g} / \mathrm{mL}$, and $1000 \mu \mathrm{g} / \mathrm{mL}$ of ciprofloxacin averaged $1.01 \pm 0.31,0.58 \pm 0.21$, and $0.12 \pm 0.04$, respectively. The optical density upon exposure to $10 \mu \mathrm{g} / \mathrm{mL}$, $100 \mu \mathrm{g} / \mathrm{mL}$, and $1000 \mu \mathrm{g} / \mathrm{mL}$ of vancomycin averaged $0.89 \pm 0.19, \quad 0.84 \pm 0.18$, and $0.80 \pm 0.19$, respectively (Fig. 5). A significant dose-related difference was noted at a high dose $(1000 \mu \mathrm{g} / \mathrm{mL})$ of cefazolin, and medium-tohigh dose of ciprofloxacin $(100 \mu \mathrm{g} / \mathrm{mL}$ and $1000 \mu \mathrm{g} / \mathrm{mL})$, but not for vancomycin.

\section{Correlation between the cell index from the xCELLigence system and WST-1 proliferation assays}

The Pearson's coefficient analysis revealed that the cell index ratio and WST-1 ratio for different antibiotic concentrations relative to the control groups showed a high correlation when the periosteal cells were cultured in moderateto-high concentrations $(100 \mu \mathrm{g} / \mathrm{mL}$ and $1000 \mu \mathrm{g} / \mathrm{mL})$ of ciprofloxacin and showed a moderate correlation for cefazolin and low dose of ciprofloxacin $(10 \mu \mathrm{g} / \mathrm{mL})$ (Fig. 6). Correlation for vancomycin was low.

Effect of different antibiotics on osteogenic gene expression RNA was isolated from the cells cultured in the XCELLigence 96-well plates after final impedance measurement. To investigate the osteogenic activity of periosteal cells in the 96-well plates, mRNA expressions were obtained by real-time PCR for $\mathrm{Cbfa1}$ and $\mathrm{OPN}$, relative to GAPDH as the endogenous control (Fig. 7). A significant decrease in Cbfa1 expression was noted for low and medium doses of cefazolin and ciprofloxacin $(10 \mu \mathrm{g} / \mathrm{mL}$ and $100 \mu \mathrm{g} / \mathrm{mL}$ ); Cbfa1 expression was undetectable at high concentrations $(1000 \mu \mathrm{g} / \mathrm{mL})$. A significant dosedependent inhibition of OPN expression was noted for low and medium doses of cefazolin $(10 \mu \mathrm{g} / \mathrm{mL}$ and $100 \mu \mathrm{g} / \mathrm{mL})$ and low dose of ciprofloxacin $(10 \mu \mathrm{g} / \mathrm{mL})$; OPN expression was undetectable with high doses of cefazolin $(1000 \mu \mathrm{g} / \mathrm{mL})$ and medium-to-high doses of ciprofloxacin $(100 \mu \mathrm{g} / \mathrm{mL}$ and $1000 \mu \mathrm{g} / \mathrm{mL})$. A significant dose-dependent inhibition of OPNp expression on exposure to cefazolin and ciprofloxacin was noted with low and medium concentrations $(10 \mu \mathrm{g} / \mathrm{mL}$ and $100 \mu \mathrm{g} / \mathrm{mL})$; OPNp expression was undetectable at high concentrations $(1000 \mu \mathrm{g} / \mathrm{mL})$. A dose-dependent inhibition of Cbfa1 expression was noted with the medium and high doses $(100 \mu \mathrm{g} / \mathrm{mL}$ and $1000 \mu \mathrm{g} / \mathrm{mL})$ of vancomycin; inhibition of OPN and OPNp expression was observed for all three concentrations of vancomycin.

\section{Discussion}

Locally applied medications, including prolotherapy injections and antibiotic spacers, and pain management, are commonly used to treat musculoskeletal disorders $[12,13]$. Local applications of antibiotics represent an important strategy for both the prevention and treatment of orthopedic infections; yet, only a small amount of prospective clinical data currently guides our practices. Additionally, concerns of systemic toxicity, as well as topical detrimental effects persist [14]. The periosteum is a well-vascularized osteogenic organ [15] and contains progenitor cells, which are responsible for callus formation and secondary bone healing after fracture, osteotomy, and even infections [16]. While local antibiotics are used to exert direct effects on bone at a cellular level [17], most studies have focused on their negative effects on stem cells and bone cells $[15,18,19]$.

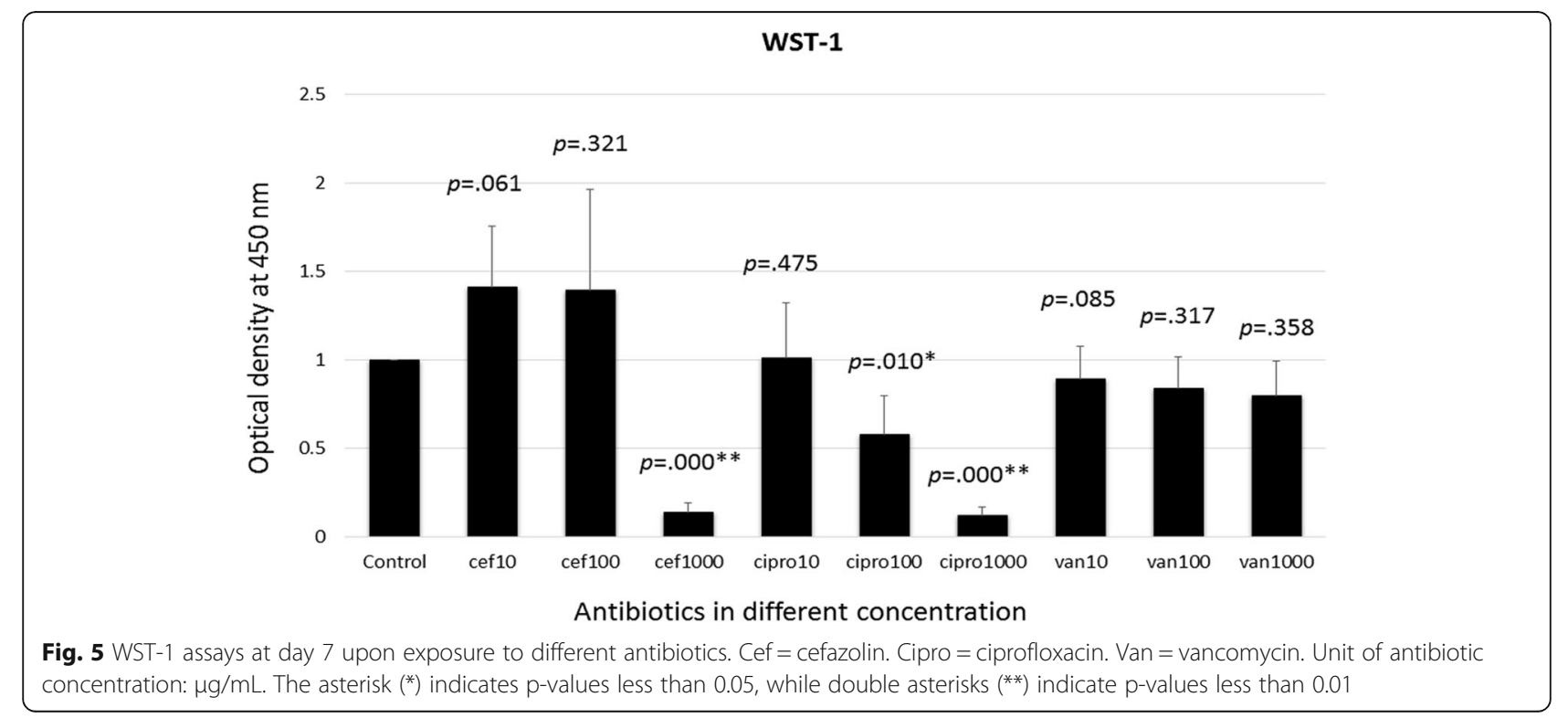



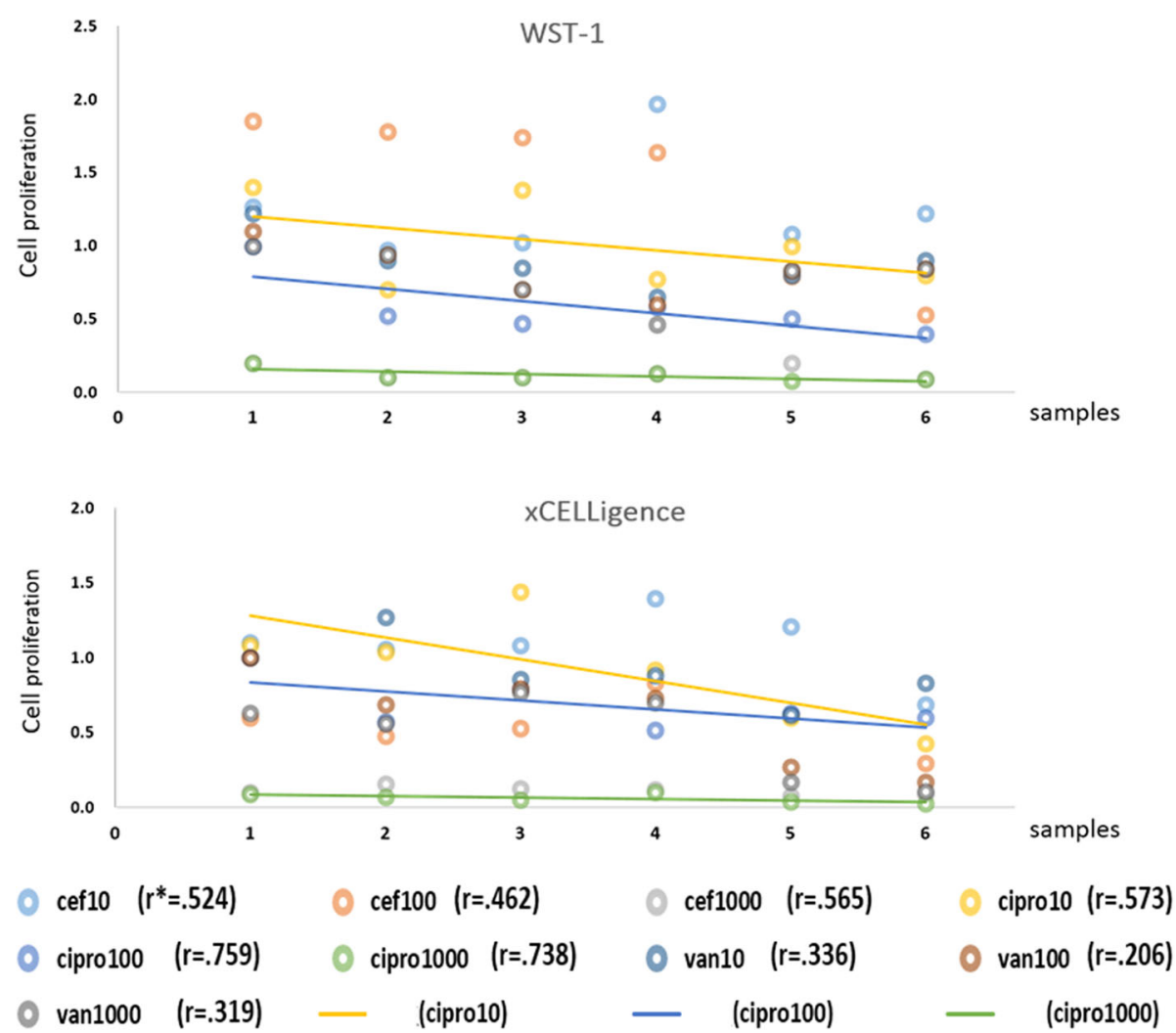

Fig. 6 Correlations between the cell index and cell proliferation results. Correlations between the cell index results from the xCELLigence system (upper diagram) and cell proliferation results from WST-1 assays using conventional cultures (lower diagram) were assessed with Pearson's correlation analysis. Pearson's correlation coefficients ( $r$ ) were calculated according to the concentrations of different antibiotics

Since the periosteum is responsible for secondary fracture union whenever absolute stability and primary bone healing is unable to be achieved, basic research on dosage optimization needs to be performed and the antibiotic dose-related proliferative and osteogenic effects on periosteal cells need to be elucidated. Our study set up an automatic, cell-based impedance model to monitor the proliferation of periosteal cells under different antibiotic concentrations while current reports had demonstrated inhibitory effects of those three antibiotics in stem cells or bone-derived cells using traditional cellular assays [20-22]. An xCELLigence E-96-well plate was used, with an optimal seeding density of $5 \times 10^{3}$ cells $/ \mathrm{cm}^{2}$, to facilitate the continuous detection of cell proliferation and to avoid phenotype drift after prolonged maintenance in monolayer cell culture [23, 24].

Traditional cell studies using WST colorimetric assay [25] observed cell proliferation in conventional culture wells, which require large numbers of cells, large volumes of reagents, and are limited in their accessibility for high-resolution and time-lapse imaging. The microfluidic cell culture array is fabricated by soft-lithography technology and designed to maintain and monitor cell proliferation continuously [26]. With the integration of an electronic circuit into the microfluidic chip [27], this system allows the real-time detection of cellular response in a stable microenvironment in multiple assay conditions [28]. In our study, a dose-dependent inhibition on periosteal cell proliferation was observed, especially after treatment with medium-to-high antibiotic concentrations, in case of all three antibiotics. Similar dose-related changes were also observed at high antibiotic concentrations in case of the WST-1 assay using conventional cell cultures but not in medium concentration of vancomycin, which was not well correlated with the result detected by the xCELLigence system. Since vancomycin had been demonstrated to exhibit different inhibition activity in cellular osteogenesis [22], real-time monitoring of cellular proliferation with correlation to genetic expression is crucial in examining the drug toxicity in periosteal cells. Pearson's coefficients showed a moderate-to-high correlation between the cell index from the microfluidic culture system and the optical densities from the WST-1 assay using conventional cell cultures; the impedance analyzer in the microfluidic culture system was more sensitive in detecting the dosedependent inhibition of cell proliferation at medium antibiotic concentrations. 
A

CBFA1

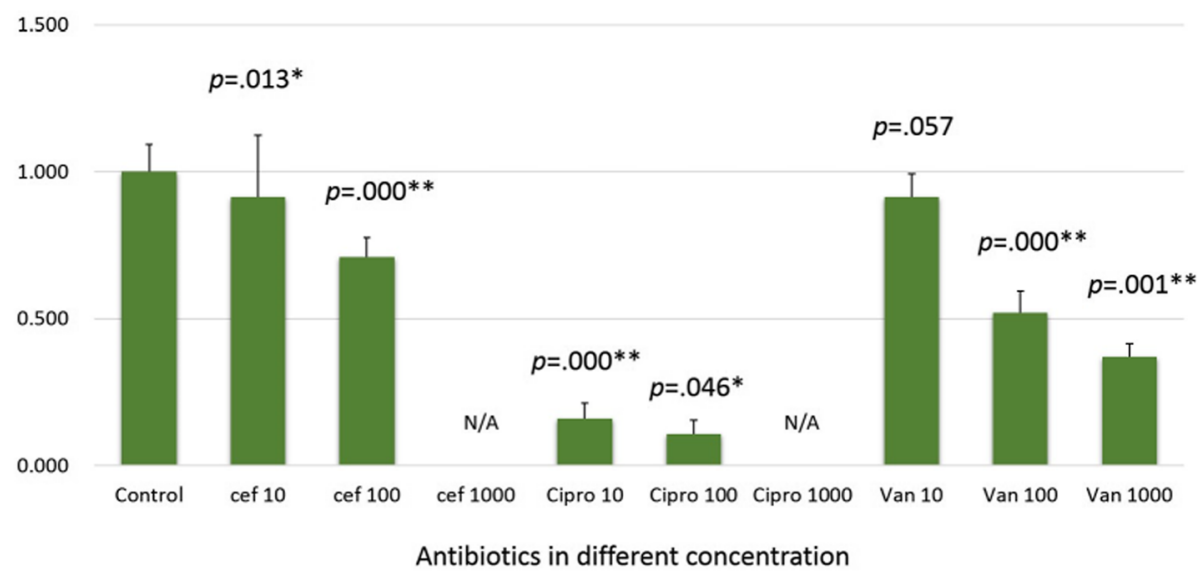

B

OPN
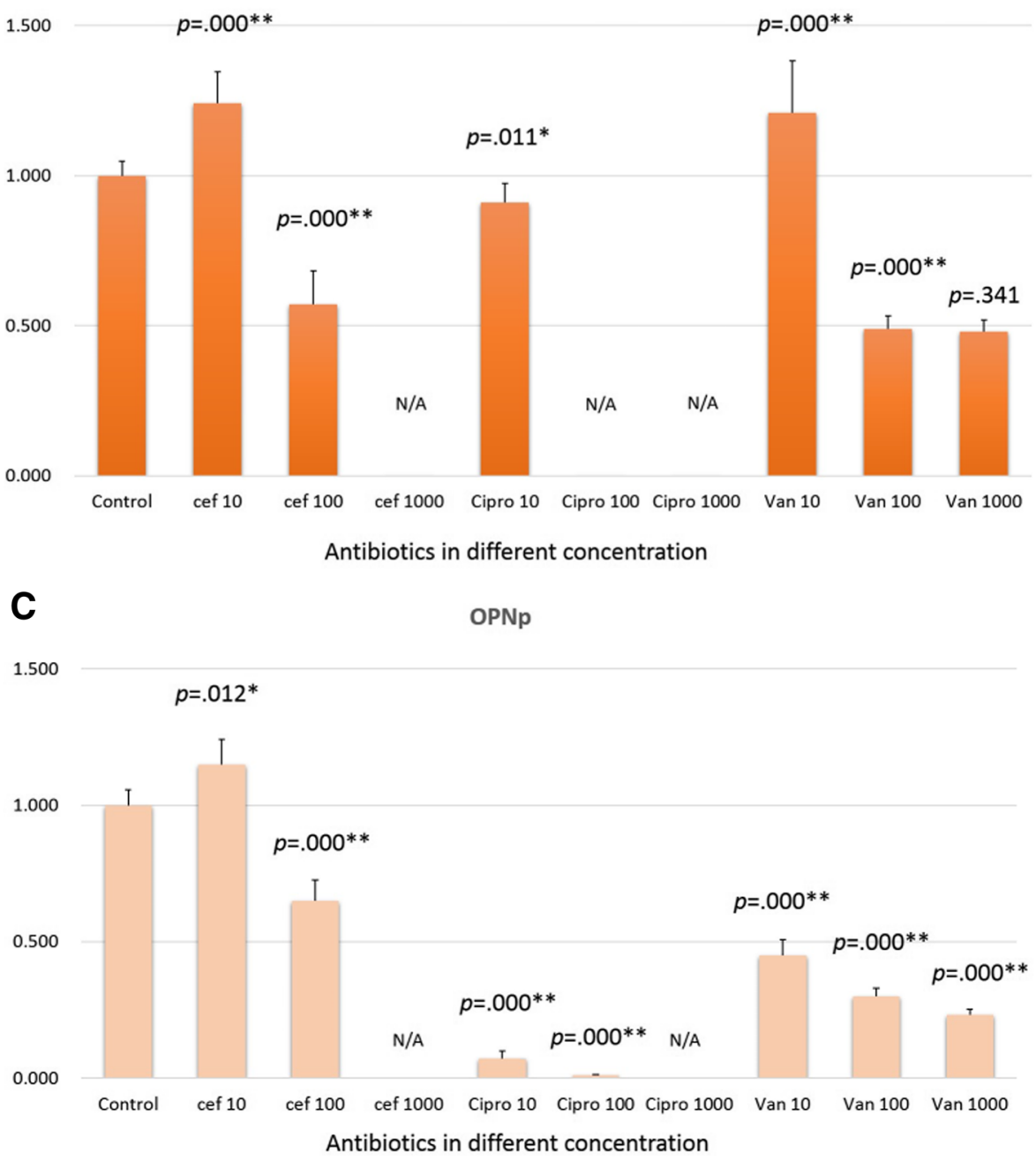

Fig. 7 Osteogenic gene expression. The gene expression of osteogenic markers relative to the expression of GAPDH as the endogenous control upon culture in the xCELLigence system at 7 days. a cbfa-1. b OPN. c OPNp. Cef = cefazolin. Cipro = ciprofloxacin. Van = vancomycin. Unit of antibiotic concentration: $\mu \mathrm{g} / \mathrm{mL}$. The asterisk $\left(^{*}\right)$ indicates $p$-value less than 0.05 , while double asterisks $\left(^{* *}\right)$ indicate $p$-values less than 0.01 
Real-time PCR analysis indicated that periosteal cells exposed to different antibiotics concentration in the xCELLigence E-96-well plate exhibited a dose-related decrease in osteogenic gene expression, which was compatible with the changes of proliferation index upon exposure to medium concentrations of the antibiotics. Although real-time PCR expressed a more sensitive detection in the dose-related changes, gene expression could be undetectable due to difficulty in the extraction of sufficient RNA in a small culture medium of 96-well plates upon exposure to high-dose antibiotics. This may highlight the distinctive potential of the xCELLigence system, which is a high-throughput analysis system, for clinical applications in identifying drug toxicity and predicting drug response in periosteal cells, and subsequent bone healing capability.

Our study has several limitations that warrant consideration. Firstly, neither this in vitro model, nor conventional cell cultures can represent in vivo conditions. Secondly, genotype survey of cbfa-1 and OPN may not fully and specifically represent the osteogenic expression of periosteal cells. Further animal studies using an infected nonunion model are mandatory to elucidate the influence of antibiotics on periosteal bone healing. Finally, only three dosages of antibiotics were selected for microfluidic assays; they may not adequately represent the integral characteristics affecting periosteal cell proliferation. In clinical applications, a more detailed survey using different antibiotic concentrations within the whole therapeutic range may be essential to clarify this dose-dependent relationship.

\section{Conclusion}

Rabbit periosteal cells harvested from the tibial periosteum were successfully cultured at optimal seeding densities in xCELLigence 96-well plates; the microfluidic biosensor system allowed the dynamic monitoring of the cultured cells. Cefazolin and ciprofloxacin exhibited significant dose-related inhibition both in cellular proliferation and osteogenic expression. Such a non-invasive, label-free impedance-based analysis can serve as a feasible alternative to conventional WST-1 assays.

\section{Abbreviations \\ Cbfa1: Core-binding factor alpha 1; DMEM: Dulbecco's modified Eagle's medium; FBS: fetal Bovine serum; GAPDH: Glyceraldehyde-3-phosphate dehydrogenase; IACUC: Institutional Animal Care and Use Committee; OPN: Osteopontin; OPNp: Osteopontin promoter; PBS: Dulbecco's phosphate- buffered saline; PCR: Polymerase chain reaction; RNA: Ribonucleic acid}

\section{Acknowledgements}

Not Applicable.

\section{Authors' contributions}

$\mathrm{AC}$, the principal investigator (PI), performed the major part of research and was responsible for the study design. CC (Co-PI) provided assistance with the cell culture / osteogenic study and manuscript composition. KFL designed the microfluidic cell analyzer and impedance-detection system and prepared this manuscript. YC provided assistance with data analysis and statistics. SU provided assistance with the setup of cell infection /antibiotics research model. All the authors have read and approved the manuscript and agree with this submission to the Journal.

\section{Funding}

This project with funding number of CMRPG3H0691 was supported by the Chang Gung Medical Foundation provided funds for the research purpose while all the study design, execution and data collection including analysis and interpretation was audited by the Institutional Animal Care and Use Committee (IACUC).

\section{Availability of data and materials}

The datasets generated during the current study are kept in the databank of Chang Gung Bone and Joint Research Center, and are available from the corresponding author on reasonable request.

\section{Ethics approval}

Institutional Animal Care and Use Committee (IACUC) approval (2015122504) was obtained to perform an animal study.

\section{Consent for publication}

Not Applicable.

\section{Competing interests}

No benefits in any form have been received or will be received from a commercial party related directly or indirectly to the subject of this article. The authors report no conflict of interest.

\section{Author details}

'Bone and Joint Research Center, Department of Orthopedic Surgery, Chang Gung Memorial Hospital-Linkou and University College of Medicine, 5th, Fu-Shin Street, Kweishan Dist, Taoyuan 333, Taiwan, Republic of China. ${ }^{2}$ Graduate Institute of Medical Mechatronics, Chang Gung University, Taiwan, Republic of China.

Received: 30 January 2019 Accepted: 4 July 2019

Published online: 26 July 2019

\section{References}

1. Furia JP, Alioto RJ, Marquardt JD. The efficacy and safety of the hematoma block for fracture reduction in closed, isolated fractures. Orthopedics. 1997; 20:423-6.

2. Mehallo CJ, Drezner JA, Bytomski JR. Practical management: nonsteroidal antiinflammatory drug (NSAID) use in athletic injuries. Clin J Sport Med. 2006:16:170-4.

3. Saccomanni B. Corticosteroid injection for tennis elbow or lateral epicondylitis: a review of the literature. Curr Rev Musculoskelet Med. 2010;3: 38-40.

4. Cancienne JM, Burrus MT, Weiss DB DB, Yarboro SR SR. Applications of local antibiotics in orthopedic trauma. Orthop Clin North Am. 2015;46:495-510.

5. Lian X, Mao K, Liu X, Wang X, Cui F. In vivo osteogenesis of vancomycin loaded nanohydroxyapatite/collagen/calcium sulfate composite for treating infectious bone defect induced by chronic osteomyelitis. J Nanomater. 2015; Article ID 261492.

6. Vistejnova L, Dvorakova J, Hasova M, Muthny T, Velebny V, Soucek K, Kubala $\mathrm{L}$. The comparison of impedance-based method of cell proliferation monitoring with commonly used metabolic-based techniques. Neuro Endocrinol Lett. 2009:30:121-7.

7. Scrace S, O'Neill E, Hammond EM, Pires IM. Use of the XCELLigence system for real-time analysis of changes in cellular motility and adhesion in physiological conditions. Methods Mol Biol. 2013;1046:295-306.

8. Atienzar FA, Gerets H, Tilmant K, Toussaint G, Dhalluin S. Evaluation of impedance-based label-free technology as a tool for pharmacology and toxicology investigations. Biosensors (Basel). 2013:3:132-56.

9. Tritten L, Braissant O, Keiser J. Comparison of novel and existing tools for studying drug sensitivity against the hookworm Ancylostoma ceylanicum in vitro. Parasitology. 2012;139:348-57.

10. Alexander D, Melanie Rieger M, Klein C, Ardjomandi N, Reinert S. Selection of osteoprogenitors from the jaw periosteum by a specific animal-free culture medium. PLoS One. 2013;8:e81674. 
11. Chiu C-H, Lei KF, Yeh W-L, Chen P, Chan Y-S, Hsu K-Y, ACY C. Comparison between $x c e$ ligence biosensor technology and conventional cell culture system for real-time monitoring human tenocytes proliferation and drugs cytotoxicity screening. J Orthop Surg Res. 2017;12:149.

12. Akpancar S, Seven MM, Tuzun HY, Gurer L, Ekinci S. Current concepts of prolotherapy in orthopedic surgery. Arch Trauma Res. 2017;6:e40447.

13. Stephens MB, Beutler Al, O'Connor FG. Musculoskeletal injections: a review of the evidence. Am Fam Physician. 2008;78:971-6.

14. Hake ME, Young H, Hak DJ, Stahel PF, Hammerberg EM, Mauffrey C. Local antibiotic therapy strategies in orthopaedic trauma: practical tips and tricks and review of the literature. Injury. 2015;46:1447-56.

15. Mckibbin B. The biology of fracture healing in long bones. J Bone Joint Surg Br. 1978;60:150-62.

16. Simmons DJ. Fracture healing perspectives. Clin Orthop Relat Res. 1985;200: $100-13$.

17. Pountos I, Georgouli T, Bird H, Kontakis G, Giannoudis PV. The effect of antibiotics on bone healing: current evidence. Expert Opin Drug Saf. 2011; 10:935-45.

18. Cohen S, Samadikuchaksaraei A, Polak JM, Bishop A. Antibiotics reduce the growth rate and differentiation of embryonic stem cell cultures. Tissue Eng. 2006;12:2025-30.

19. Llobet L, Montoya J. Lo' pez-Gallardo E, Ruiz-Pesini U. Side effects of culture media antibiotics on cell differentiation. Tissue Eng Part C Methods. 2015;21: $1143-7$.

20. Pilge H, Fröbel J, Lensing-Höhn S, Zilkens C, Krauspe R. Cefazolin irreversibly inhibits proliferation and migration of human mesenchymal stromal cells. Biomed Res Int. 2016;2042687:1-6.

21. Weber D, Hiergeist A, Weber M, Dettmer K, Wolff D, Hahn J, Herr W, Gessner A, Holler E. Detrimental effect of broad-spectrum antibiotics on intestinal microbiome diversity in patients after allogeneic stem cell transplantation: lack of commensal sparing antibiotics. Clin Infect Dis. 2018. https://doi.org/1 0.1093/cid/ciy711 [Epub ahead of print]

22. Booysen E, Sadie-Van Gijsen H, Deane SM, Ferris W, Dicks LMT. The effect of vancomycin on the viability and osteogenic potential of bone-derived mesenchymal stem cells. Probiotics Antimicrob Proteins. 2018. https://doi. org/10.1007/s12602-018-9473-0 [Epub ahead of print].

23. Fang J, Hall BK. In vitro differentiation potential of the periosteal cells from a membrane bone, the quadratojugal of the embryonic chick. Dev Biol. 1996; 180:701-12.

24. Hutmacher DW, Sittinger M. Periosteal cells in bone tissue engineering. Tissue Eng. 2003;9:545-64.

25. Jo CH, Kim JE, Yoon KS, Shin S. Platelet-rich plasma stimulates cell proliferation and enhances matrix gene expression and synthesis in tenocytes from human rotator cuff tendons with degenerative tears. Am J Sports Med. 2012;40:1035-45.

26. Inamdar NK, Borenstein JT. Microfluidic cell culture models for tissue engineering. Curr Opin Biotechnol. 2011;22:681-9.

27. Tandon N, Marsano A, Maidhof R, Numata K, Montouri-Sorrentino C, Cannizzaro C, et al. Surface-patterned electrode bioreactor for electrical stimulation. Lab Chip. 2010;10:692-700.

28. Hung PJ, Lee PJ, Sabounchi P, Lin R, Lee LP. Continuous perfusion microfluidic cell culture array for high-throughput cell-based assays. Biotechnol Bioeng. 2005;89:1-8.

\section{Publisher's Note}

Springer Nature remains neutral with regard to jurisdictional claims in published maps and institutional affiliations.

Ready to submit your research? Choose BMC and benefit from:

- fast, convenient online submission

- thorough peer review by experienced researchers in your field

- rapid publication on acceptance

- support for research data, including large and complex data types

- gold Open Access which fosters wider collaboration and increased citations

- maximum visibility for your research: over $100 \mathrm{M}$ website views per year

At BMC, research is always in progress.

Learn more biomedcentral.com/submissions 